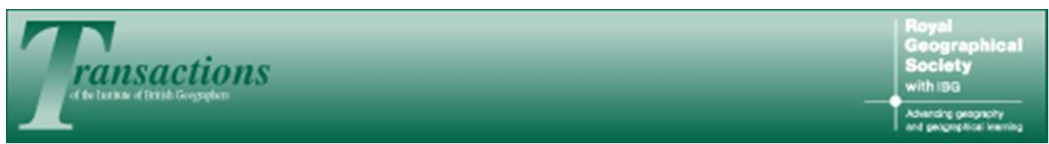

\title{
Justice, neoliberal natures, and Australia's water reforms
}

\begin{tabular}{|c|c|}
\hline Journal: & Transactions of the Institute of British Geographers \\
\hline Manuscript ID: & TIBG-RP-Sep-2013-0084.R2 \\
\hline Manuscript Type: & Regular Paper \\
\hline Keywords: & Justice, Neoliberal Natures, Water Management, Australia \\
\hline Abstract: & $\begin{array}{l}\text { Scholars studying the neoliberalization of nature (and political ecologists } \\
\text { more broadly) have been notably concerned with justice, but have } \\
\text { underspecified their own conceptions of justice and have failed to seriously } \\
\text { question or investigate what kind (or kinds) of justice is actually being } \\
\text { pursued in the context of neoliberalism. In this paper, I argue that a more } \\
\text { robust treatment of justice is required, building on recent calls for a more } \\
\text { reflexive approach to normativity in critical human geography. I make this } \\
\text { argument by drawing on a study examining how justice is being mobilized } \\
\text { in Australia's neoliberal water reforms through a series of semi-structured } \\
\text { interviews with water policymakers and industry professionals. I show that } \\
\text { the justice being pursued through these reforms is multivalent, but } \\
\text { coalesces around an allocative framework I call the 'basic needs plus } \\
\text { market' framework. This framework ultimately finds its moral compass in a } \\
\text { utilitarian conception of distributive justice, and this utilitarianism both } \\
\text { facilitates neoliberalization and tempers its expression. Understanding } \\
\text { neoliberalization as a means to broader normative ends, I suggest, has } \\
\text { considerable potential for both explaining the contradictions and } \\
\text { contestations scholars have argued are intrinsic to 'actually existing } \\
\text { neoliberalism' and opening up opportunities for productive critique and } \\
\text { engagement. }\end{array}$ \\
\hline
\end{tabular}




\section{Justice, neoliberal natures, and Australia's water reforms}

\section{Abstract}

Scholars studying the neoliberalization of nature (and political ecologists more broadly) have been notably concerned with justice, but have underspecified their own conceptions of justice and have failed to seriously question or investigate what kind (or kinds) of justice is actually being pursued in the context of neoliberalism. In this paper, I argue that a more robust treatment of justice is required, building on recent calls for a more reflexive approach to normativity in critical human geography. I make this argument by drawing on a study examining how justice is being mobilized in Australia's neoliberal water reforms through a series of semi-structured interviews with water policymakers and industry professionals. I show that the justice being pursued through these reforms is multivalent, but coalesces around an allocative framework I call the 'basic needs plus market' framework. This framework ultimately finds its moral compass in a utilitarian conception of distributive justice, and this utilitarianism both facilitates neoliberalization and tempers its expression. Understanding neoliberalization as a means to broader normative ends, I suggest, has considerable potential for both explaining the contradictions and contestations scholars have argued are intrinsic to 'actually existing neoliberalism' and opening up opportunities for productive critique and engagement.

\section{Keywords}

Justice, neoliberal natures, water management, Australia

Acknowledgements

[to be added after review] 


\section{Introduction}

In the last two decades, neoliberal modes of environmental governance have proliferated worldwide, and geographers have been prominent in critiquing the attendant transformations of humanity's interaction with nature. The empirical focus has been on previously common pool resources such as wetlands, fisheries, carbon and water, which have increasingly been commodified, marketized and privatized. This 'neoliberal natures' literature, much of which adopts a neo-Marxist theoretical lens (and requires no recapitulation here), argues strongly that the processes and implications of neoliberalization are geographically contingent, contested, and contradictory (e.g. Larner 2000, 2003; Peck \& Tickell 2002; Heynen \& Robbins 2005). But it remains almost universally critical of both neoliberalism writ large and the myriad neoliberalizations it studies, and at the heart of this critique is the assertion that neoliberalism is unjust and that the processes and policies associated with it create or exacerbate injustice. The 'justice' of neoliberalism is seen as largely stable and coherent.

This raises a question for me: whether or not I agree that neoliberalism has some particularly pernicious characteristics (I do), if neoliberalism is variegated in both expression and experience, surely its justice implications are too? Declaring neoliberal environmental governance unjust requires both normative argumentation to establish a conception of justice against which to judge it and an understanding of what kind (or kinds) of justice is actually being pursued where neoliberal mechanisms are prominent. As Noel Castree warned neoMarxists interested in nature's neoliberalization in 2003, "assuming, or even asserting, normative standpoints - both at the level of modes of critique and specific normative justifications within and between these modes - simply leaves too many important questions unanswered" (Castree 2003, 292). 
In this paper, I make the case for a more robust treatment of justice by scholars interested in nature's neoliberalization, though by extension I am talking to political ecologists and urban political ecologists too, building on the calls which have been emerging from around the discipline for a more critical, reflexive approach to normativity (Sayer \& Storper 1997; Smith, D.M. 2001; Olson \& Sayer 2009; Barnett 2011; Fincher \& Iveson 2012). I develop this argument with reference to Australia's recent water reforms, which display all the hallmarks of a 'neoliberal project' (Bakker 2005) (authors' reference). I argue that the architects of neoliberalization in the Australian water sphere espouse a remarkably multivalent conception of justice, seeking to build a framework for allocating water based around first providing for people's 'basic human needs' and then subsequently using a market to redistribute the remaining water resource. Though the rhetoric of marketization has been prominent and it would be tempting to make quick normative judgments on the injustice of Australia's new approach to water allocation and distribution, I argue that this 'basic needs plus market' allocative framework actually subjugates the pursuit of neoliberalism (or what might be called 'neoliberal ideals') to the pursuit of a utilitarian conception of distributive justice. Neoliberalization in Australian water governance must therefore be understood as a means rather than an end. As a result I question the repeated assertions in the neoliberal natures literature that neoliberalism is fundamentally unjust. Instead, I argue that understanding neoliberalization as a means of achieving more fundamental normative ends has considerable potential for helping to explain the contingency of neoliberalism and the contradictions and contestations which scholars have convincingly argued characterize it, opening up opportunities for productive critique and engagement.

To begin with, I problematize the way justice is mobilized in the neoliberalization of nature literature. I argue that justice underpins much of the critique yet attracts little explicit attention or theorization beyond that. Scholars generally have not carefully justified or 
explained their own conceptions of justice, though in aggregate David Harvey's socialist formulation of justice developed in Social Justice and the City (1973) hangs heavily over the literature, much of which simply adopts it as 'fit for purpose', and proceeds from there. Perhaps as a result of this lack of reflexive attention to justice, scholars have also failed to seriously question or investigate what kind (or kinds) of justice is actually being pursued in the context of the 'neoliberal' cases they are studying, or how the mobilization of competing conceptions of justice may in fact shape the trajectory of neoliberalization. I then examine Harvey's work and the work following in his vein in more depth, arguing that whilst a Marxist conception of justice does emerge, this work highlights the importance of maintaining a critical, deliberate and thorough engagement with the meanings and debates over justice. The body of the paper is then devoted to developing my argument with reference to Australia's recent water reforms.

\section{Problematizing justice in the neoliberal natures literature}

Neoliberal natures and justice narratives

Justice looms large in the neoliberal natures literature, and this is not surprising. The literature sits within a broader geographical critique of neoliberalism, which has "focused on the deleterious impact that its manifestations have on social justice" (Smith, A. et al. 2008, 240-241), and draws significant inspiration from work in political ecology which drew the first clear lines of connection between social injustice and environmental degradation (see, e.g., Blaikie 1985; Forsyth 2008). Central to the critique has been how environments, natures and resources have become sites of capitalistic accumulation, drawing particularly on David Harvey's (2003) reformulation of Marx's (1976 [1867]) thesis of 'primitive accumulation' as an ongoing process of 'accumulation by dispossession'. By this reading, the privatization of resources formerly considered 'commons' is unjust because it appropriates for a few what had previously been the property of - or at least freely accessible to-all. Erik Swyngedouw 
$(2005,82)$ thus argues that privatization is simply the "official terminology" for accumulation by dispossession, which "is nothing else than a legally and institutionally condoned, if not encouraged, form of theft". But critics are rarely as direct as Swyngedouw. Instead, scholars tend to express their concern that neoliberal mechanisms for governing nature are unjust by building narratives in which neoliberalization is associated with inequality, inequity, exclusion, enclosure, loss of (political) agency and dispossession. Justice is rarely directly addressed—let alone subjected to critical scrutiny — yet it is central to their critique. Matthew Himley summarized the tenor of the literature well when he observed that critiques of the neoliberalization of nature "underscore the necessity of analyzing ... how governance arrangements may codify inequality ... and in the process reproduce unjust social relations" (Himley 2008, 444).

To give just a few examples, Jessica Budds argues that Chile's neoliberal 1981 Water Code exacerbated inequalities between large and peasant farmers, giving large-scale farmers greater control over water at the expense of peasant farmers whose access is increasingly curtailed. She concludes that "natural resource management under market principles diminishes, rather than fosters, social equity and ecological concerns" (Budds 2004, 337). Ben Page $(2005,303)$ argues that the community-run provision of water in Tombel, Cameroon is "more just than the plan to coerce everyone into paying". Rhodante Ahlers $(2005,57)$ argues that "unequal gendered access to resources is perpetuated and legitimized by the introduction of market mechanisms in the water sector" in Mexico and Bolivia, a point also taken up by Adrienne Roberts $(2008,544)$, who argues that "neoliberal globalization is increasingly exacerbating inequalities based on class, gender and race”. Finally, a wide range of scholars have documented the ways in which privatization serves to reinforce the privileged position of elites at the expense of the majority (e.g. Goldman 2007; Laurie \& Crespo 2007; Dubash 2006). Becky Mansfield thus argues that "Property rights are at the 
center of a massive change in the political economy of the oceans ... that enclose for a few what was once the property of all" (Mansfield 2004, 324-325).

Some scholars have attempted to go beyond highlighting negative justice implications associated with neoliberalism to examining how neoliberalism has transformed mainstream understandings of what justice entails. Karen Bakker's work has been particularly influential in building this argument. Bakker argued that the privatization of the English and Welsh water utilities in the 1980 s was underpinned by two policy changes. Firstly, from policies designed to promote geographical equalization of water costs to those designed to promote full-cost recovery (and hence geographically different water rates); and secondly, from basing water rates on the rateable value of land towards charging based on consumption (facilitated through installation of water meters). The effect of these policy changes was to subtly transform the meaning of justice in the water sphere from 'social equity' to 'economic equity' (Bakker 2001, 2003a). This argument that justice has been transformed along increasingly economic lines has been widely accepted in the literature (e.g. Smith, L. 2004; Perreault 2005; Laurie \& Crespo 2007; Davidson \& Stratford 2007; Roberts 2008; Harris 2009). It is in this vein that Lailla Smith argues that "The corporatization model [in Cape Town] undermines public accountability because it inherently involves a policy shift that moves away from political processes towards greater technical intervention that places a premium on efficiency at the expense of equity", which is "particularly dangerous in a society that is replete with inequalities" (Smith, L. 2004, 382).

Bakker's argument finds support from Chukwumerije Okereke, whose work on two international environmental conventions forms the context for his argument that justice is being redefined along more neoliberal lines: "the most important determinant of the "success" of equity norms in environmental regimes" he argues, "is the extent to which they 
"fit" with dominant neoliberal economic ideas and structures" (Okereke 2006, 26). Together, Bakker and Okereke's work suggests that justice is being neoliberalized, and both are uncomfortable with this. Bakker draws comfort from what she sees is the inevitability of a Polanyian double movement, which re-institutes some of the social protections lost in the process of privatization. Okereke is less hopeful: "the general philosophy of neoliberal patterns of governance and the key narratives with which this philosophy is advanced remain irreconcilable with the idea of global environmental justice and North-South equity" (Okereke 2008b, 13). But both arguments point to the fact that proponents of neoliberalization are active in pursuing some form of justice agenda, even if it involves attempting to normalize oppositional justice claims within an overarching neoliberal paradigm, as Ryan Holifield (2004) argued the Clinton administration sought to do in its engagement with the Environmental Justice movement in the USA. This work brings justice into the foreground, something sorely needed in the neoliberal natures literature, even though I think it is insufficient to see justice as yet another domain to be colonized by the neoliberal rationality.

But the paucity of direct treatments of justice highlights the fact that as it stands, the neoliberal natures literature lacks a systematic, thorough and reflexive theorization of justice to lend weight to its critical project. Justice concepts tend to be used in a rather ad-hoc manner with little of the nuance that characterizes the treatment of, for instance, the contingency of manifestations of neoliberalism. The time has come to address this lacuna, particularly given cognate shifts within human geography towards a more ethically and normatively aware as well as engaged mode of critique (Smith, D.M. 2000; Olson \& Sayer 2009; Barnett 2011). Simply put, a clear moral framework supported by normative argumentation is required to explain why the ills being associated with neoliberalization (most commonly inequality, but also enclosure, exclusion, dispossession and others) must be 
considered unjust, to move beyond observations and assertions to more meaningful critique. Yet this normative reflexivity and reflection is noticeably lacking in the neoliberal natures literature. Instead, the literature appears to derive its moral compass and justice lens predominantly from David Harvey's socialist formulation of justice developed in Social Justice and the City (SJC), which sits within a broader neo-Marxist geographical scholarship.

\section{The neo-Marxist geographical theorization of justice}

SJC was the product of Harvey's realization that the geographic analysis of the kind he was pursuing at the time must in some way be connected to social and moral philosophy, but he “could find scarcely any literature on this topic" (Harvey 1973, 9). Published just two years after John Rawls' paradigm-shifting A Theory of Justice (1999 [1971]) which set the tone for moral and political philosophy for at least a generation, SJC was far ahead of its time. One of the most novel and productive things about $S J C$ was the way Harvey radically shifted his own position on how justice should be theorized in response to the demands imposed on him by his reading of the contemporary city. It would take philosophers another 30 years to make a similar shift from exploring "idealized models of justice" to "starting from more worldly, intuitive understandings of injustice, indignation, and harm, and building up from there" (Barnett 2011, 252). In one of the defining moments of $20^{\text {th }}$ century human geography, in SJC Harvey abandoned a 'liberal' formulation of social justice in favour of a 'socialist' one, and proceeded to set out the basic contours of a (Marxist) geographical theorization of justice (Harvey 1973; Smith, N. 1996). This shifted heralded the Marxian turn in human geography without which the entire literature on nature's neoliberalization may well have not existed, and certainly would have taken on a vastly different form if it had (Barnett 2011). Subsequently, scholars (including Harvey) working in the neo-Marxist tradition have built on Iris Young's (1990) five principles of justice (exploitation, marginalization, powerlessness, 
cultural imperialism, and violence), to which Harvey added the ecological dimension as a sixth (Harvey 1992, 1996).

In SJC (urban) inequalities - particularly the inequality of income and the way its redistribution tends to benefit the rich at the expense of the poor-are Harvey's indicators of injustice. His argument is that these inequalities are not the outworkings of some conspiracy or corruption in the system, but rather are the natural by-product of market forms of exchange, generated by the same mechanisms by which the market economy achieves efficiency. Writing in an edited anthology some years later, Soja paraphrases Harvey:

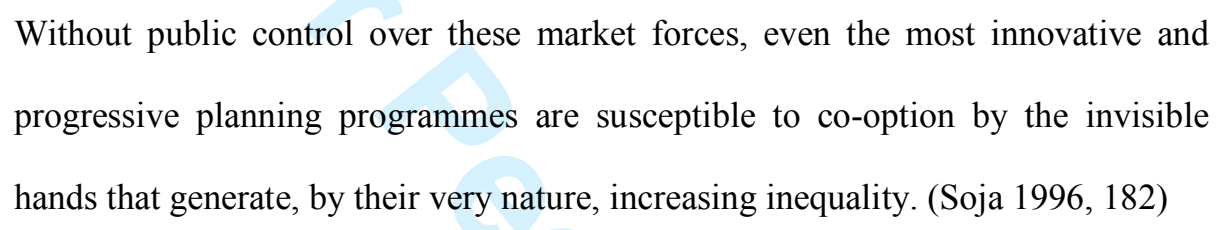

If the normal operation of a market economy produces such deleterious inequality, then action must be taken. Simply put, the 'normal injustice' of market capitalism is grounds for its overthrow in the name of social justice, and socialism is the 'better alternative'. Harvey's account of the market economy with its embedded justice assertions has had a vast influence on both critical urban studies and critical political economy, and in it we can identify the key normative assumptions embedded in critiques of nature's neoliberalization.

But can we forgive scholars for adopting Harvey's (socialist) formulation of justice as 'fit for purpose', and proceeding from there? Not according to Neil Smith, who argues that Harvey's theorization of justice fails to resolve "the dilemma of social justice for the left". Of which dilemma is Smith speaking, and how has Harvey failed to resolve it? There is certainly no hint of a dilemma within the neoliberal natures literature. The dilemma is that even if one overlooks the difficulties within Marx's own engagement with justice (see Geras 1985, 1992; McCarney 1992), whilst Marxism provides a number of compelling reasons to be concerned 
about justice, it has thus far failed to provide an alternative conception of justice to that of liberal egalitarianism (i.e. Rawls, see Kymlicka 2002; Smith, D.M. 1994). Harvey has failed to resolve it, because his theorization of justice, with its six principles and universal aspirations, "lacks the motive force to shift the discussion from the liberal bedrock of ideals of justice - an admittedly tall order but a vital one” (Smith, N. 1996, 132).

This dilemma, though, has been exacerbated by a systemic inattention to justice within Marxist scholarship more broadly. Merrifield and Swyngedouw $(1996,1)$ observe that justice "has tended not to preoccupy Marxist thinkers too much" (Merrifield \& Swyngedouw 1996, 1). But Neil Smith goes further:

\begin{abstract}
It may be heretical, but I am almost inclined ... to admit that the paralysis of the left concerning a well elaborated discourse of social justice actually expresses something of importance, something we should take seriously. ... It is not, of course, that Marx and Engels had no commitment to justice. Clearly they were all about justice, but how was this political commitment expressed? (Smith, N. 1996,
\end{abstract} 133)

So it seems some remedial work is required to revive the comparative critical trajectory pioneered by Harvey in SJC. Such was the influence of SJC that scholars working broadly in the Marxian tradition (including those working on neoliberal natures and related areas such as urban political ecology) have rarely felt compelled to develop their own critical engagement with the theories of justice Harvey himself was so engaged with. Instead, scholars have implicitly adopted Harvey's socialist formulation of justice as 'fit for purpose' without any sustained normative reasoning as to why, perhaps assuming as Harvey does that "Putting the inequalities at the top of the environmental agenda directly challenges the dominant discourses (be they of the standard, ecological modernization or wise use variety)" (Harvey 
1996, 385). Ira Katznelson thus argues that Harvey's abandonment of liberalism in SJC cost Marxist critics the ability to "connect with, rather than override, the concerns raised by Rawls and other recent liberal thinkers about justice, equality and social peace" (Katznelson 1996, 60). ${ }^{1}$ Here Smith and Katznelson are in agreement - neo-Marxist critiques would be enhanced by engaging with, rather than dismissing, liberal conceptions of justice. Katznelson proposes a normative pluralism as more productive than Harvey's increasingly dogmatic socialism:

\begin{abstract}
Rather than choose between them, as in his [Harvey's] attempt to move to better and stronger ground, I prefer to insist, first, on the possibility of a social process approach to the analysis of liberalism (as well Marxism) and the city; and, second, that a rotation in our axes of attention and explanation can be salutary. (Katznelson
\end{abstract} $1996,58)$.

Harvey explores justice pluralism in his broader précis of the literature on Environmental Justice (EJ) in Justice, Nature and the Geography of Difference (1996). He observes that environmental discourses can be crudely mapped onto different principles of social justiceenvironmental management to utilitarianism, radical animal rights to libertarianism, and deep ecology to radical egalitarianism — and that all of these formulations are both theoretically valid and observable in the EJ movement. This leaves scholars "with a case of determining which is the most socially just theory of social justice" (Harvey 1996, 397-398; also, Harvey 1992, 595). Justice pluralism is one way of making this determination - allowing different conceptions of justice to have different weight depending on the context. But Harvey questions justice pluralism both practical and ethical grounds: it provides little guidance on why to opt for one blend of principles over another and is more likely to be perverted by

\footnotetext{
${ }^{1}$ Intriguingly, Katznelson also argues that $S J C$ pivots on the work of Karl Polanyi, but in a "denuded" form simplified and not fully articulated. This is arguably true for the neoliberal natures literature too. Polanyi has emerged as a fulcrum point of its critical analysis, and it has demonstrated empirically the fact that (neo)liberalism "is inherently multiplex and contradictory" (Katznelson 1996, 60).
} 
existing elites. Flagging his destination up-front by citing Marx-"Between equal rights, force decides" (p. 399)—Harvey argues that EJ faces a choice: "ignore the contradictions [of pluralism], remain with the confines of their own particularist militancies" or "treat the contradictions as a fecund nexus to create a more transcendent and universal politics" (p. 400). If EJ choses the latter (clearly Harvey's preferred option) then Harvey thinks it will have to "displace the hegemonic powers of capitalism" (p. 400), which will require EJ to "radicalize the ecological modernization discourse. And that requires confronting the underlying the fundamental underlying processes ... that generate environmental and social injustices" (p. 401). At this point he is defending very nearly the same ground he claimed in SJC, only from a different perspective:

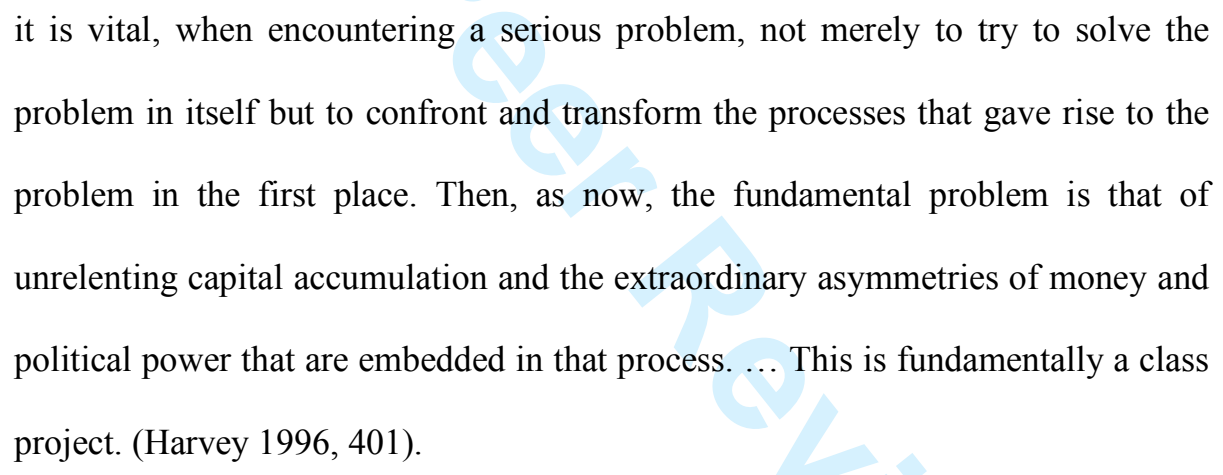

Harvey picked up this same point in an interview for New Left Review in 2000, when he argued that "there's a case for reintroducing the idea of justice, but not at the expense of the fundamental aim of changing the mode of production" (Harvey 2000, 92). Yet he still saw this terrain vacant at that time, since "there is a sound tactical reason for the Left to reclaim ideas of justice and rights, which I touch on in my latest book, Spaces of Hope. If there is a central contradiction in the bourgeoisie's own ideology throughout the world today, it lies in its rhetoric of rights" (Harvey 2000, 92-93). 
This rendering of the problem is equally visible in the neoliberal natures literature, which like Harvey focuses on problems of accumulation and capital/power asymmetries. But perhaps Harvey did not give justice pluralism enough of a chance. Both the cognate literature on Environmental Justice (EJ) and work from a post-structuralist perspective see considerable purchase in justice pluralism as a strategy to both examine existing injustices and imagine more just futures. In the case of EJ, justice pluralism was initially driven by pragmatism as the EJ movement sought to articulate and unify the diverse demands of EJ claimants in particular geographical contexts (as Harvey observes). But in recent years justice pluralismparticularly the idea that justice is trivalent or even multivalent-has emerged as a much more deliberate theoretical tactic to broaden the theorization of justice away from the liberal foundations which characterized 'early' EJ (Schlosberg 2007, 2013; Walker 2009, 2012; Holifield et al. 2009). For postmodern scholars such as Edward Soja, the pursuit of justice requires a "more open cultural politics of justice that is relational, contextualized, situationally specific, and achievable primarily through strategic coalitions that confront and redirect the social, spatial, and historical workings of power" (Soja 1996, 191; also, Soja 2010b). Both the "liberal strategy of redistribution and equality of opportunity" and the "socialist strategy of class struggle" (Soja 1996, 191) have a role to play in this struggle for justice, rather than being seen as antithetical to each other.

There is clearly still appetite for justice-theorizing within critical human geography, particularly urban geography, where the 'right to the city' has emerged as a preoccupation of some scholars, blending the insights of Harvey with those of Henri Lefebvre. Debates have focussed particularly on the spatiality of justice, or more accurately injustice (Iveson 2011; see, e.g. Soja 2010a; Marcuse 2010). This, like work in EJ, has increasingly focussed on what MacLeod and McFarlane (2014) describe as the 'intersectionality' of everyday experiences of injustice (Fincher \& Iveson 2012), structured by a conceptual scaffolding focussing on 
questions of difference and recognition rather than merely on the distributional questions posed by capitalistic modes of production (Young 1990; Fraser 1997, 2009). It is not surprising that Barnett $(2011,247)$ argues that these are "the two areas of debate in geography where the concept of 'justice' is most seriously at stake". Like the neoliberal natures literature, scholarship on the right to the city looks back to Harvey for inspiration, but it exhibits a much keener appreciation of the importance of adequately and reflexively theorizing justice. As Iveson $(2011,252)$ observes, the two main protagonists-Peter Marcuse and Edward Soja - “are impatient with 'critique' which is so focused on identifying the injustices of contemporary capitalist urbanisation that it fails to take the next step of identifying the possibilities for justice in the present." In other words, theorizing justice helps move beyond what Barnett (2005) calls the "consoling" image of neoliberalism and neoliberalization in leftist academia.

\section{Returning to neoliberal natures}

What this discussion has highlighted is the fact that mobilizing justice as a mode of critique must not be entered into lightly. Justice is far from a concrete, specifiable, or uncontentious concept, and as such positionality is fundamentally important to any justice-based critique (Olson \& Sayer 2009). Even if we could assume a common normative agenda predicated on a common neo-Marxist theoretical frame, it is not clear that either the diagnosis or the prescription to remedy injustices associated with environmental governance would look very different from liberal ones. But we cannot even begin to discuss these issues without a more robust engagement with justice in the literature, something akin to the way in which scholars moved beyond a focus on neoliberalism to an analysis of neoliberalization. In the remainder of this paper, then, I take up Katznelson's admonition that "a rotation in our axes of attention and explanation can be salutary" (see above) to examine what kind (or kinds) of justice is actually being pursued by the proponents of neoliberalism, and how the mobilization of 
competing conceptions of justice may in fact shape and influence the trajectory of neoliberalization, with reference to just one example of the neoliberalization of nature Australia's recent water reforms. This analytical pivot reveals that justice is not just another domain to be colonized by a 'neoliberal rationality', as Okereke (2008b) and Holifield (2004) suggest it has been. Rather, conceptions of justice underpin, are grafted onto, and are articulated with neoliberalism and vice versa. This leaves little room for grand pronouncements about the 'injustice of neoliberalism', but does open up new explanations for the contingency of neoliberalism. In this, I believe, lie some as-yet underutilized opportunities for productive critique.

\section{Unpacking the justice of Australia's water reforms}

Like in numerous other contexts around the world, recent reforms to Australian water governance have embraced market environmentalism as the long-term solution to allocation dilemmas in both rural and urban areas, manifested in increasingly visible and frequent crises of water availability (authors reference). Ownership of water has been transferred from government to private hands as rural water licenses have been converted into (tradeable) entitlements and urban utilities have been corporatized, cross-subsidies eliminated, and fullcost recovery pricing implemented. The reform agenda has been driven forward by the highest levels of government through the intergovernmental forum the 'Council of Australian Governments' (COAG); initially through its 1994 'Water Resource Policy' and more recently through the 2004 'National Water Initiative' (NWI), signed in 2004 (COAG 1994; 2004; authors reference).

Clearly, the neoliberalization of Australian water is proceeding apace. But how does justice figure in this ambitious roll-out of neoliberal governance logics and what sort of justice is being pursued through it? To answer these questions requires a two-pronged approach. 
Firstly, it requires an understanding of the content of the reforms: what changes to the allocation, ownership and governance of water are being proposed. But secondly, it requires an understanding of the intent of the reforms: to what end (or ends) is water governance being reconfigured. Examining the policies and legislation the reforms have generated is clearly the first step. However, justice is rarely mentioned in water policy documents, and where it does appear it is generally as a high-level goal or constraint. The justice discourses which find their way into such official documents are also inevitably sanitized signifiers, stripped of the competing ideas, differing priorities and operational compromises that are intrinsic to policy formulation and implementation. Moreover, the intergovernmental COAG platform through which Australia's water reforms have been pursued privileged the knowledge of the working groups of policy makers which do most of the policy development (for further discussion of the priveliged role of public sector experts in the Australian policy process, see Pusey 1991; Henry 2007).

As a result, at the heart of this study is a series of 31 semi-structured interviews with 28 key water policymakers and 4 industry professionals ${ }^{2}$ which sought to investigate how justice is being articulated by those pursuing and implementing the neoliberal policies which attract scholars' critical attention. Of these, 16 were public servants working in federal government departments or agencies, most of whom occupied executive-level (i.e. senior management) positions and had been deeply involved in the reforms. My discussions with them centred on how they thought water should be allocated and how different water uses should be prioritized, their evaluation of the COAG reforms, their views on the role of government and the use of economic instruments in water allocation, and their views on and understanding of fairness, equity and justice in water management. The interviews were transcribed and analysed using qualitative content analysis. The aim was to unbundle 'neoliberalism' from a

\footnotetext{
${ }^{2}$ One interview had two interviewees. Of the four industry professionals, three worked for umbrella groups representing industry interests, and one for a national NGO.
} 
preconceived formulation of 'in/justice', and to map the justice concepts being mobilized in support of the reforms onto mainstream notions of social justice drawn from political philosophy. In this sense, the study fits within the tradition of "understanding the ordinary ways in which norms, values and justifications are folded into and out of assemblages of spatial practice" (Barnett 2012, 384). It also builds on work from Environmental Justice, which has been notable for mapping notions of justice from political philosophy onto the politics and practice of real-world situations (Schlosberg 2004, 2007).

In the rest of this section, I examine through this lens the way justice has been mobilized in the context of Australia's water reforms. The reformers were in near unanimous agreement one two guiding principles for water allocation: firstly, the government-secured provision of water for 'basic human needs'; and secondly, the use wherever possible of markets to allocate and redistribute the remaining water resource. I show that underpinning this 'basic needs plus market' framework is a multivalent conception of justice, unsettling the narrative of neoliberalization leading to injustice typical of the neoliberal natures literature. However multivalent it is, though, this conception of justice is nevertheless consistent. I examine two possible explanations for the simultaneous advocacy of basic needs provision and marketization, concluding that the most convincing is to understand neoliberalization not as an end in itself, but instead as a means to a broader utilitarian governance agenda. Rotating "our axes of attention and explanation" in this way-to borrow Katznelson's phrase-proves very useful in explaining the contradictions and contestations of 'actually existing neoliberalism' in the Australian water sphere, and opens up new opportunities for productive critique.

\footnotetext{
${ }^{3}$ Thanks to one of the anonymous referees for suggesting this angle, and thereby forcing me to bring together two otherwise only loosely connected strands of my own work!
} 


\section{Multivalence and consistency: seeking just water allocation by providing basic needs and establishing a market}

Discussion of water allocation was structured around three themes: firstly, which users of water should be prioritised; secondly, how that priority should be decided; and finally, which mechanisms should be used to allocate water in the context of competing demands. In these discussions, policymakers divided water into conceptual categories — or 'buckets' — according to its use: water for basic human needs, environmental water, and the consumptive pool. Within each of these buckets, the importance, type and provision of justice differed (Table I). Justice was considered most important in the basic human needs bucket, where a liberal egalitarian philosophy of justice was dominant. Most interviewees thought that justice demanded a statutory guarantee that water for 'basic human needs' would be provided at zero or nominal cost to all people. Within the environmental water bucket, justice was deemed to be important in the transition from a situation of over-allocation to one of sustainable extraction. Justice in this bucket was defined in utilitarian terms, since achieving 'sustainable extraction' would maximise societal welfare both for present and future generations, and a government-led but market-oriented program was envisaged to achieve 'sustainable extraction'. Within the consumptive pool, the importance of justice was ambiguous. Many interviewees simply assumed that the market was just, but a few actively asserted that the market was just. Justice in this bucket was libertarian, since it was derived from the ability of individuals to exercise their free will through trading of water entitlements.

\section{[ Table I: Approaches to justice in the allocation of water in Australia ]}

It is immediately apparent from Table I that embedded within the Australian water reforms are multiple justice claims and aspirations. Indeed, the very act of dividing the water resource into multiple buckets was underpinned by justice aspirations and constraints. The 
multivalence of the justice being pursued stands in clear distinction to the stability and singularity of 'neoliberal justice' in the neoliberal natures literature. But it is equally clear that to consider only the differing articulations of justice within each of the three buckets would be missing the point. The three buckets were constituent parts of a coherent allocative framework, and-leaving aside the environmental 'bucket' of water for a moment- two principles structured this framework. The first was that water must be provided for basic human needs before any other water is allocated. The second was that, as far as possible, the market should be used to make allocative decisions. One respondent explained:

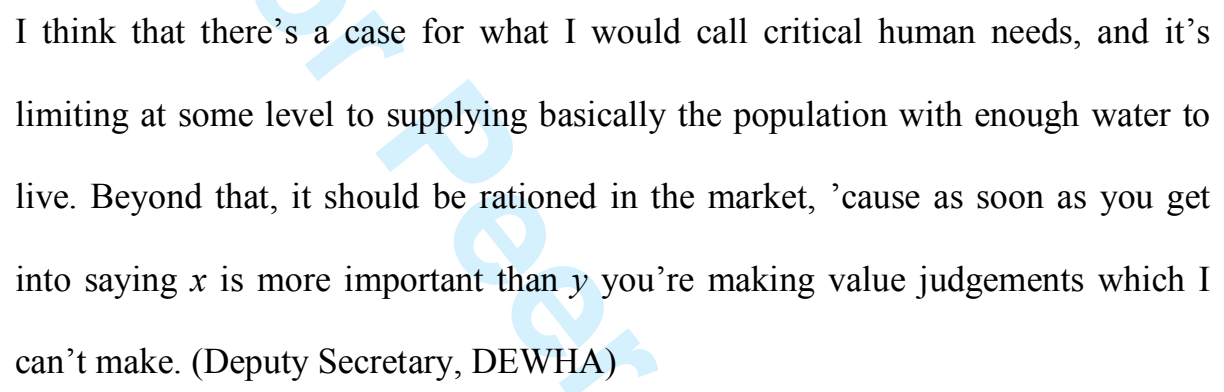

Another, a general manager at the National Water Commission, explained "I don't think it can be equity in terms of everybody being able to get the same allocation of water; it's an input to production and it should be mainstreamed like other inputs to production", but immediately qualified this: "everybody, every household, should be able to have an affordable amount of water for a normal standard of living". The 'basic needs plus market' framework holds together in unity two conceptions of justice that most philosophers consider to be poles apart: liberal egalitarianism and libertarianism.

As conceptually problematic as this is, the 'basic needs plus market' framework is also intuitively attractive. In a liberal, democratic society, few would argue against the provision of some form of guaranteed minimum, particularly of water. But few would argue, either, with the notion that some mechanism must be provided to facilitate the redistribution of 
water, and the market presents as a reasonable institution to facilitate this exchange. The provision of water for basic human needs is grounded in the idea that equal human rights demand equal provision of water. But the marketization imperative beyond that seems to rely on a libertarian conception of justice which prioritises individual freedom "rather than picking winners or choosing who gets the water according to some arbitrary judgements scale, like $x$ is good and $y$ is bad (First assistant secretary, Federal Department of the Environment, Water, Heritage and the Arts - DEWHA).

What I want to argue, though, is that neither egalitarianism nor libertarianism ultimately underpins the 'basic needs plus market' framework of the neoliberalization of water in Australia associated with it. They are dominant in their respective buckets, but these buckets are merely goals of water allocation: to provide for people, to ensure environmental sustainability, and to facilitate economic productivity. When viewed as a coherent approach to water allocation, the 'basic needs plus market' allocative framework ultimately appeals to a utilitarian concept of justice, albeit one couched in economic language. The provision of a statutory 'basic human needs' entitlement and the creation of a market on top of that seek to maximise the value of water to society as a whole. As Interviewee \#1 argued:

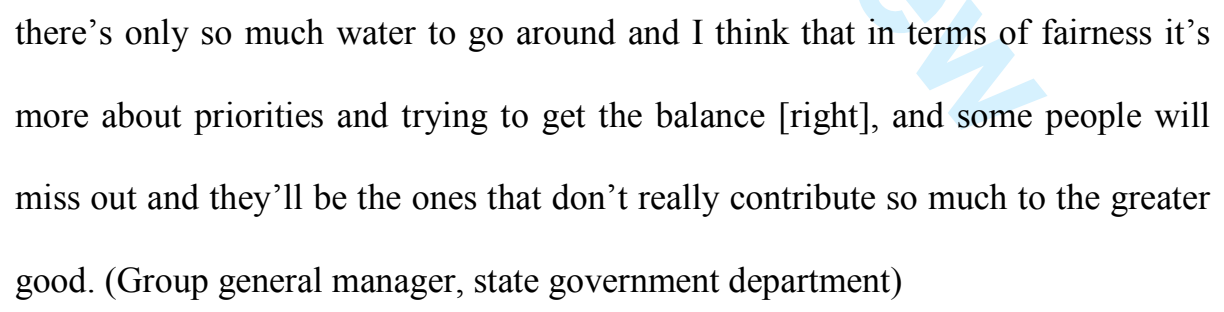

If the ultimate goal of Australia's water reforms is to restructure the allocation and governance of water around more utilitarian objectives, then where does that leave us in terms of theorizing and understanding the neoliberalization of nature, given the centrality of neoliberalism in shaping both the policies at the heart of the reforms and the broader 
governmentality advocated through it (Larner 2000)? I first turn my attention to the contradictory implications of the basic needs plus market framework for neoliberalism Clearly, it promotes the practical neoliberalization of water policy. But at the same time, by its very nature it casts doubt on the adequacy of neoliberalism to deliver on justice goals. I then seek to account for its emergence as the core allocative framework of these 'neoliberal' reforms. I argue that it makes sense if we understand neoliberalization as an attempt to realize a utilitarian conception of distributive justice.

Based on this analysis, normative contestations about justice are a key fulcrum around which neoliberalism pivots. But there is no such thing as 'neoliberal justice', nor should neoliberalism itself be critiqued as 'unjust'. Rather, 'actually existing neoliberalism' is shaped by diverse normative goals and rationalities, paired with pragmatic considerations and pre-existing norms and structures. But it is only ever a means, never an end, and in Australia's water reforms its goal is to maximise utility rather than liberty. Taking this seriously, I contend, opens up much more productive opportunities for critique and engagement than regurgitating tired arguments as to the injustice of capitalism.

\section{Basic needs plus market: dialogues with neoliberalism} Supporting neoliberalism

On the one hand, the basic needs plus market framework undoubtedly supports the ongoing neoliberalization of the water sector in Australia, because it provides an ethical rationale for both continued marketization and the increasingly economic framing of water management dilemmas. With market exchange the key redistributive mechanism employed, the framework is a significant departure from Australia's historical water allocation, where water was publically owned, and its use regulated by government-issues licenses. The expansion of the market is supported by an appeal to Robert Nozick's $(1974,153)$ theory of justice as entitlements, where "If each person's holdings are just, then the total set (distribution) of 
holdings is just". The same shift from 'social' equity to 'economic' equity that Bakker (2001) observed accompanying the privatization of the English and Welsh water utilities is visible in Australia, where water allocation no longer seeks to ensure everyone has access to water on equal terms, but rather that no-one pays for water for the benefit of others (e.g. through crosssubsidization).

In addition to promoting the 'natural justice' of market exchange, the basic needs plus market framework re-casts the role of government to that of long-term planner, basic needs guarantor and environmental advocate. By curtailing government involvement this way, the basic needs plus market framework acts as a 'techno-administrative justice fix', relieving governments of the ethically difficult and politically fraught task of deciding which water uses are most deserving, particularly within the consumptive pool, and cementing the primacy of markets in allocative decision-making. Policymakers considered this a good thing, arguing that past governments had either avoided these decisions or made them poorly, resulting in the gross over-allocation underpinning contemporary scarcity crises (authors reference). In the same way that Rose and Miller (1992) argued that the public hope that 'experts' can resolve regulatory problems without the need for political involvement, in Australia experts hope that 'the market' can resolve distributional dilemmas without the need for political involvement.

Finally, the 'basic needs plus market' model in a sense facilitates neoliberalization precisely because it guarantees basic needs outside the market frame. Smith (2000) has argued that it is hard to find a theory of justice that does not make room for the provision of basic human needs, and citizens in Australia confirmed this in practice, arguing that a governmentprovided statutory guarantee of water for basic needs was essential to any allocative framework. Providing for basic needs outside the market frame thus acts to legitimize, facilitate and sustain the broader extension of neoliberal logics into the sector, in the same 
way that Marshall argued in the $19^{\text {th }}$ and early $20^{\text {th }}$ centuries "The common purpose of statutory and voluntary effort [in developing social rights and citizenship] was to abate the nuisance of poverty without disturbing the pattern of inequality of which poverty was the most obviously unpleasant consequence" (Marshall 1998 [1950], 107).

\section{Challenging neoliberalism}

But at the same time as it supports marketization, the basic needs plus market framework insists that water for basic needs be provided outside the market frame. This suggests that policymakers remain unconvinced about the ability of the market to independently achieve justice goals, or at least that they acknowledge that the community-at-large is not satisfied with markets as a 'just' allocative tool. The basic needs element of the framework thus reflects the view that the ability to exercise liberty is less important than ensuring a basic equality of access to water. Embedded within the basic needs plus market framework is precisely the kind of double movement which Karl Polanyi (2001 [1944]) famously argued was intrinsic to the development of capitalism in the $19^{\text {th }}$ century. Non-market provision of water for basic needs thus emerges to curtail the extension of the market into the domestic sphere and the household, and to reassert the importance of government in overseeing the water sector. It should be noted, too, that this more egalitarian view about the justice that water allocation should provide remains deeply embedded in water legislation despite the influence of neoliberal ideology. The Water Act 2007 (Commonwealth) (Part 2A) explicitly prioritizes water for domestic human consumption, and in this is entirely consistent with prereform legislation at the state level. ${ }^{4}$

This leads to the second challenge the basic needs plus market framework poses to neoliberalization, which is that it situates neoliberal governance mechanisms within a broader

\footnotetext{
${ }^{4}$ Particularly the Water Act 1912 (NSW) (Section 22B(4)), the Water Management Act 2000 (NSW) (Section 58, Section 60(3)).
} 
governance framework which is not necessarily neoliberal. For instance, although the perceived procedural justice of the market (particularly its transparency and impartiality) certainly contributed to the perceived justice of the 'basic needs plus market' allocative framework, policymakers also emphasized how that market would be situated within a government-led, planning-based governance framework which provided avenues for public 'participation' in the planning process. In Australia, despite the expansion of neoliberal rhetoric and the enthusiastic adoption of neoliberal policy mechanisms (most notably marketization and pricing), a justice lens reveals that the neoliberalization of water governance is dependent on a broader commitment to maximizing the utility of water for the Australian people. In short, neoliberalization is being pursued in aid of a utilitarian conception of distributive justice. In the next section, I explore the implications of this for how Australia's water reforms are understood, setting the scene for a broader discussion in the concluding section about the implications of this research for the critique of neoliberal natures.

\section{Explaining basic needs plus market: neoliberal means and utilitarian ends}

As a consequentialist philosophy, utilitarianism does not define 'justice' in terms of a preexisting moral 'law', nor even in terms of a prior social contract, but in terms of outcomes. In utilitarian terms, a just allocative framework is one which maximizes the aggregate welfare of society. As such, it provides a compelling explanation for why basic needs and the market are articulated together. Consider again the two components of the framework: firstly, the nonmarket provision of water for basic human needs; and secondly, the application, as far as possible, of the principles of an open and competitive market.

The provision of basic needs is essential to maximise aggregate welfare because the 'unhappiness' of a large number of people who could be negatively affected by a purely 
market allocative frame would outweigh the 'extra happiness' of a small number who by virtue of existing water entitlements and/or wealth would be able to maximise their welfare through the market. By providing for everyone's basic needs, the basic needs plus market framework asserts that a minimum level of individual welfare is required, not to achieve a goal of equality, but to maximise overall societal welfare. This explains why despite their general advocacy of marketization, little support could be found amongst policymakers for unfettered marketization. It also explains why the definition of 'basic needs' they adopted was never defined in volumetric terms (like the 20L/day minimum nominated by the World Health Organization): the provision of water 'basic needs' they envisaged was that which would result in the greatest aggregate level of welfare when combined with market-based allocation. As a senior manager at the National Water Commission explained it, "a reasonable amount for a reasonable standard of living without necessarily free water for the swimming pool approach".

By the same token, the market is essential to maximise aggregate welfare because it promotes a redistribution of water in favour of users who value it more highly in economic terms, whilst providing a transparent mechanism to compensate those holding existing entitlements. In utilitarian language, it allows maximum utility to be derived from the use of water, and does so in a way which encourages maximum water use efficiency, which policymakers saw as essential for both social and environmental goals. In this way both the non-market provision of water for basic needs and the subsequent market redistribution of water both contribute towards the overall goal of maximizing the 'efficiency' of water use, in order to maximise aggregate social welfare.

But the market frame can also be seen as a pragmatic measure to maximise the (mainly economic) value extracted from water, which can then be redistributed to fulfil socially- 
defined goals (which could even include limited equalization). The non-market provision of basic needs, likewise, can be seen as an efficiency-maximizing allocative decision, because, as Howe $(1996,31)$ argued, "the best way of achieving efficiency in the long run may be to build equity into the project" (see also Bakker 2001; Howe \& Ingram 2005). The exercise of liberty is thus facilitated to the extent that it does not infringe upon a socially-agreed modicum of equality, and this springs from a fundamental concern that the least fortunate are provided for by society.

Scholars of neoliberal natures have argued that 'actually existing neoliberalism' is inherently contradictory, contested and contingent (Larner 2000; Brenner \& Theodore 2002; Castree 2006; Springer 2010) But the contradictions of the basic needs plus market framework begin to dissolve when neoliberalization is understood not as an end in itself, but rather as a means to a broader utilitarian end. Subjugating neoliberalism to utilitarianism explains, for instance, why the water sector in Australia remains so tightly controlled by government despite the rhetoric about the benefits of marketization which sometimes borders on propaganda. It also explains why the planning and administrative approvals process mandated by government often confounds the operation of the very markets they created (see Crase et al. 2008), to the point where a number of scholars have questioned whether government really believes in the ability of markets to deliver desired social and environmental objectives (e.g. Connell et al. 2005; Connell \& Dovers 2006; Hussey \& Dovers 2006). On this point, from the perspective of the reformers there is no contradiction and the commitment of government to markets is largely irrelevant. Both the refashioned direct involvement of government and marketization can be understood as tools to ensure that Australia as a whole derives the maximum aggregate utility from its water resources, both now and into the future, and they will persist as long as they contribute to this goal. 
To use a pie analogy, in utilitarian terms markets are like a good knife: vital to divide the pie effectively, but a spoon is just as important in preparing the pie and a fork a much better tool for eating the pie with. As a result, the expansion of markets and shrinking direct role for government creates no particular ethical dilemmas, particularly where utility is primarily being defined in economic terms. The relevant ethical debate from the perspective of the policymakers is that of where the boundaries of the market should be set to maximise aggregate welfare, and this debate is proceeding apace. As Crase and O'Keefe $(2009,80)$ observed "Water policy formulation in Australia is increasingly contentious and the debate about the efficacy of water markets shows no signs of weakening. Nevertheless, water markets are not about to be discarded from the policy makers toolbox, and nor should they be." Understanding neoliberalization as a means to broader normative ends helps explain why neoliberalism is so contradictory: it is precisely because neoliberalism is manipulated in aid of socio-political objectives rather than vice versa.

It also points to the issue of multiple subject positionalities. ${ }^{5}$ It is clear that views on justice differ within society. Some people give primacy to liberty whereas others give primacy to equality (or community). The overarching market frame thus caters to the justice desires of libertarians, and the non-market provision of basic needs caters to the justice desires of egalitarians. But this conflict may not just be between people or groups. Rather, the basic needs plus market allocative framework might actually be an attempt to reconcile two conflicting notions of justice within each individual. Mark Sagoff argues that each person is both citizen and consumer, and that the values we espouse as citizens might regularly conflict with our interests as consumers: "The conflict within individuals, rather than between them, may be a very common conflict. The individual as a self-interested consumer opposes himself as a moral agent and a concerned citizen" (Sagoff 2008, 60-61). Applied to water allocation,

\footnotetext{
${ }^{5}$ Thanks to $|\mathrm{MR}|$ for pointing this link out to me.
} 
Sagoff's 'citizen-consumer' dialectic suggests that the justice that I desire as a consumer —of paying only for the water I actually use-is irreconcilable with the justice that I desire as a citizen - that no-one should be without water, regardless of their ability to pay. As a citizen I may be committed to an egalitarian conception of justice, but as a consumer I may simultaneously be committed to a libertarian notion of justice. Sagoff argues that given this conflict, 'rational' policy could be based on either citizen or consumer values, with different implications for the policy process and outcomes. The basic needs plus market framework may in fact be an attempt to reconcile the dual values each person holds, and in so doing avoid the normative choice between two different rationalities. By guaranteeing that no-one will go without water which they require for their sustenance and a (socially-mediated) minimum quality of life, it attempts to address the value placed on equality as a citizen. By using the market beyond that, it attempts to address the consumer interest that 'I should not pay for another's water usage'.

This, of course, moves far beyond the typology of 'neoliberal justice' which dominates critiques of market environmentalism, in which neoliberalism colonizes the spaces of justice and by processes of co-option squeezes out oppositional definitions of justice (Okereke 2008a; Holifield 2004). It also challenges Bakker's (2003b, 191) argument that "consistent with the ideology underlying privatization of the utility industries, individuals are treated as customers buying a commodity, rather than as citizens entitled to a service." In Australia, individuals are treated as both "citizens entitled to a service"-albeit a service limited to sustaining their (poorly but expansively defined) 'basic needs' — and "consumers buying a commodity". The citizen identity is prioritized in the sense that basic needs are provided first, but this is an instrumental support for the continued expansion of the consumer identity and its colonization of previously socialized spheres such as the negotiation of environmental 
water allocations, the funding and operation of urban water infrastructure, and the structural adjustment of rural communities.

\section{Rethinking the justice of neoliberal natures}

This paper started by arguing that the neoliberal natures literature, though notably concerned with justice, has under-theorized it, and though contributors have strongly asserted that neoliberalization results in derogations of justice, supporting this assertion with a variety of examples, there has been a complete failure to engage with or study substantively how justice is being pursued through such policies. This has led to a narrative in which injustices are connected straightforwardly with neoliberal policies or programmes. This narrative is inadequate. In the body of the paper I have demonstrated with reference to Australia's water reforms that the justice being pursued in the context of neoliberalization is both multivalent and ethically coherent. In Australia, neoliberalization is just one facet of a broader utilitarian project which in the end is decisive in the kinds of justice being pursued and delivered. In a sense, neoliberalization in Australia exists within a particular 'moral economy', in the sense that Wolford and Nehring use it to examine protests over food security in Haiti, Honduras and Bolivia (Wolford 2005; Wolford \& Nehring 2013). Paying careful attention to the justice actually being pursued through neoliberal policies in this way both helps specify the objects of critique - the actual processes and aspirations which might be considered problematicand also opens up fertile new avenues for normative contestation and productive engagement to enhance justice. It begins to break open 'neoliberalism' as a normative black-box, though clearly there is much left to do.

What are the implications of this study? First, careful attention to the justice being pursued through neoliberalization breaks down the simplistic narrative of neoliberalization leading to injustice, replacing it with a much more nuanced and engaged account which inspires 
engagement rather than paralysis. In this sense, it has taken up the call for critical georgraphers to more explicitly engage with normativity (Sayer \& Storper 1997; Smith, D.M. 2001; Olson \& Sayer 2009; Barnett 2011). This paper has demonstrated that neoliberalization in Australia has been shaped to fit into the prevailing utilitarian normative agenda of the reformers, rather than the success of justice norms being regulated by their compatibility with the pre-existing neoliberal economic order, as Okereke (2008a) argued. I would contend that the obduracy of the markets being established in Australia and the associated redefinition of 'efficiency' in economic terms raises significant ethical questions worthy of normative debate. But such debate must start from a careful and reflexive engagement with the justice being pursued to avoid logical fallacies of normative reasoning.

Second, understanding the normative aspirations embedded within and underpinning processes of neoliberalization proves fruitful in explaining the contradictions and contestations which commentators have come to accept as typical of 'actually existing neoliberalism'. In Australia, understanding the reforms as contributing to a broader utilitarian agenda explains why the reformers remain committed to government provision for basic human needs outside the market sphere, which appears to challenge the central contention of neoliberal ideology; namely, that market allocation is the best allocation. The market becomes one part (albeit a central part) of an allocative framework in which the best allocation is defined as that which maximises aggregate welfare. There is something very Polanyian about this process, since as the sphere of the market expands, so too do social mechanisms to counter the "pernicious effects of a market-controlled economy" (Polanyi 2001 [1944], 80). Government remains ultimately responsible for devising and maintaining an allocative framework for the good of society overall, but markets may (and, in current Australian water policy, do) play a significant role in this framework. The reason for this, as argued in this paper, is that marketization serves the utilitarian interests of the reformers well. 
Considerable attention has been devoted to documenting the way neoliberalism manifests itself differently across space and time, co-opting competing ideologies and internalising contradictions (Springer 2010), but many of these contradictions arguably dissolve when it is understood as a means to broader normative ends. This does not of course mean that utilitarianism always forms the basis of neoliberalization - far from it — but it does mean a recommitment to avoiding totalizing analyses of neoliberalization (Larner 2000; Barnett 2005).

Finally, paying attention to what kind of justice is being pursued through processes of neoliberalization provides angles for more productive critique and engagement with the real policies being implemented, because it forces us to focus on the actual policies and their actual effects, rather than settling into tired old ideological trenches. Three threads of potential engagement are immediately apparent in the Australian case. Firstly, if neoliberalization is a means to a utilitarian end, then the extension of the market is far from a 'given' and the design and operation of the market could potentially be shaped to achieve (for instance) the goals of communities and interest groups rather than capital. Secondly, there is clearly still room for political debate about where (and how) the boundaries of the market are set, a decision that will have significant implications for who wins and who loses as a result of marketization. Finally, new opportunities are afforded for developing ethical bases for environmental allocations of water, such as developing the notion of environmental flows as 'social goods' to underpin their primacy over extractive use.

More broadly, seeing neoliberalization as a means rather than an end opens up the possibility for a reinvigorated democratic politics of water being developed to challenge or balance the technocratic and administrative allocation generally associated with neoliberalism. Neoliberalization may appear to excavate the possibility of 'proper politics' which engender 
real, transformational possibilities (Swyngedouw 2009, 2010), but as this case in Australia shows, understanding properly the normative commitments underpinning neoliberalization is the starting point for rekindling such political debate. 


\section{References}

Ahlers R 2005 Gender Dimensions of Neoliberal Water Policy in Mexico and Bolivia: Empowering or Disempowering? in Bennett V, Davila-Poblete S and Nieves Rico M eds Opposing currents: The politics of water and gender in Latin America, University of Pittsburgh Press, Pittsburgh PA 53-71

Bakker KJ 2001 Paying for water: water pricing and equity in England and Wales Transactions of the Institute of British Geographers 26 143-164

Bakker KJ 2003a From public to private to ... mutual? Restructuring water supply governance in England and Wales Geoforum 34 359-374

Bakker KJ 2003b An Uncooperative Commodity: Privatizing Water in England and Wales Oxford University Press, Oxford

Bakker KJ 2005 Neoliberalizing Nature? Market Environmentalism in Water Supply in England and Wales Annals of the Association of American Geographers 95 542-565

Barnett C 2005 The consolations of 'neoliberalism' Geoforum 36 7-12

Barnett C 2011 Geography and ethics: Justice unbound Progress in Human Geography 35 246-255

Barnett C 2012 Geography and ethics: Placing life in the space of reasons Progress in Human Geography 36 379-388

Blaikie P 1985 The political economy of soil erosion in developing countries Longman, London

Brenner N and Theodore N 2002 Cities and the Geographies of "Actually Existing Neoliberalism" Antipode 34 349-379

Budds J 2004 Power, Nature and Neoliberalism: The Political Ecology of Water in Chile Singapore Journal of Tropical Geography 25 322-342

Castree N 2003 Commodifying what nature? Progress in Human Geography 27 273-297

Castree N 2006 From neoliberalism to neoliberalisation: consolations, confusions, and necessary illusions Environment and Planning A 38 1-6

COAG, (Council of Australian Governments) 1994 Council of Australian Governments Communiqué, 25 February 1994: Attachment A - Water Resource Policy

COAG, (Council of Australian Governments) 2004 Intergovernmental Agreement on a National Water Initiative 
Connell D and Dovers S 2006 Tail Wags Dog-Water Markets and the National Water Initiative Public Administration Today 8 17-23

Connell D, Dovers S and Grafton RQ 2005 A critical analysis of the National Water Initiative The Australasian Journal of Natural Resources Law and Policy 10 81-107

Crase LR, Dollery BE and Byrnes J 2008 An intersectoral comparison of Australian water reforms Water Policy 10 43-56

Crase LR and O'Keefe SM 2009 Accounting for Hydrology in Water Trade: A cautionary note Public Policy 4 71-82

Davidson J and Stratford E 2007 En(gender)ing the debate about water's management and care - views from the Antipodes Geoforum 38 815-827

Dubash NK 2006 Water, markets, and embedded instutions in western India in Peet R and Watts $\mathbf{M}$ eds Liberation Ecologies: Environment, development, social movements, Routledge, London 218-243

Fincher R and Iveson K 2012 Justice and Injustice in the City Geographical Research 50 231-241

Forsyth T 2008 Political ecology and the epistemology of social justice Geoforum 39 756764

Fraser N 1997 Justice Interruptus: Critical Reflections on the "Postsocialist" Condition Routledge, New York

Fraser N 2009 Who Counts? Dilemmas of Justice in a Postwestphalian World Antipode 41 281-297

Geras N 1985 The Controversy About Marx and Justice New Left Review I/150 47-85

Geras N 1992 Bringing Marx to Justice: An Addendum and Rejoinder New Left Review I/195 37-69

Goldman M 2007 How "Water for All!" policy became hegemonic: The power of the World Bank and its transnational policy networks Geoforum 38 786-800

Harris L 2009 Gender and emergent water governance: comparative overview of neoliberalized natures and gender dimensions of privatization, devolution and marketization Gender, Place and Culture 16 387-408

Harvey D 1973 Social Justice and the City Edward Arnold, London 
Harvey D 1992 Social Justice, Postmodernism and the City International Journal of Urban and Regional Research 16 588-601

Harvey D 1996 Justice, Nature and the Geography of Difference Blackwell Publishers, Cambridge MA

Harvey D 2000 Reinventing Geography New Left Review 4 75-97

Harvey D 2003 The New Imperialism Oxford University Press, Oxford

Henry K 2007 Challenges Confronting Economic Policy Advisers Public Policy 2 89-98

Heynen N and Robbins P 2005 The Neoliberalization of Nature: Governance, Privatization, Enclosure and Valuation Capitalism Nature Socialism 16 5-8

Himley M 2008 Geographies of Environmental Governance: The Nexus of Nature and Neoliberalism Geography Compass 2 433-451

Holifield R 2004 Neoliberalism and environmental justice in the United States environmental protection agency: Translating policy into managerial practice in hazardous waste remediation Geoforum 35 285-297

Holifield R, Porter M and Walker G 2009 Spaces of Environmental Justice: Frameworks for Critical Engagement Antipode 41 591-612

Howe CW 1996 Water Resources Planning in a Federation of States: Equity versus Efficiency Natural Resources Journal 36 29-36

Howe CW and Ingram H 2005 Roles for the public and private sectors in water allocation: lessons from around the world in Kenney DS ed In Search of Sustainable Water Management: International Lessons for the American West and Beyond, Edward Elgar, Cheltenham 25-68

Hussey K and Dovers S 2006 Trajectories in Australian Water Policy Journal of Contemporary Water Research \& Education 135 36-50

Iveson K 2011 Social or spatial justice? Marcuse and Soja on the right to the city City 15 251-259

Katznelson I 1996 Social Justice, Liberalism and the City: Considerations on David Harvey, John Rawls and Karl Polanyi in Merrifield A and Swyngedouw E eds The Urbanization of Injustice, Lawrence \& Wishart, London 45-64

Kymlicka W 2002 Contemporary Political Philosophy: An Introduction Oxford University Press, Oxford 
Larner W 2000 Neo-liberalism: Policy, Ideology, Governmentality Studies in Political Economy 63 5-25

Larner W 2003 Neoliberalism? Environment and Planning D: Society and Space 21 509512

Laurie N and Crespo C 2007 Deconstructing the best case scenario: lessons from water politics in La Paz-El Alto, Bolivia Geoforum 38 841-854

Macleod G and McFarlane C 2014 Introduction: Grammars of Urban Injustice Antipode 46 $857-873$

Mansfield B 2004 Neoliberalism in the oceans: "rationalization," property rights, and the commons question Geoforum 35 313-326

Marcuse P 2010 Spatial justice: derivative but causal of social justice in Bret B, GervaisLambony P, Hancock C and Landy F eds Justices et Injustices Spatiales, Presses Univeritaires de Paris Ouest, Paris 75-94

Marshall TH 1998 [1950] Citizenship and Social Class in Shafir G ed The citizenship debates: a reader, University of Minnesota Press, Minneapolis 93-111

Marx K 1976 [1867] Capital: A Critique of Political Economy Penguin Books, London

McCarney J 1992 Marx and Justice Again New Left Review I/195 29-36

Merrifield A and Swyngedouw E 1996 Social Justice and the Urban Experience in Merrifield A and Swyngedouw $\mathbf{E}$ eds The Urbanization of Injustice, Lawrence \& Wishart, London 1-17

Nozick R 1974 Anarchy, State, and Utopia Basil Blackwell, Oxford

Okereke C 2006 Global environmental sustainability: Intragenerational equity and conceptions of justice in multilateral environmental regimes Geoforum 37 725-738

Okereke C 2008a Equity Norms in Global Environmental Governance Global Environmental Politics 8 25-50

Okereke C 2008b Global Justice and Neoliberal Environmental Governance: Ethics, sustainable development and international co-operation Routledge, London

Olson E and Sayer A 2009 Radical Geography and its Critical Standpoints: Embracing the Normative Antipode 41 180-198

Page B 2005 Paying for water and the geography of commodities Transactions of the Institute of British Geographers 30 293-306 
Peck J and Tickell A 2002 Neoliberalizing Space Antipode 34 380-404

Perreault T 2005 State restructuring and the scale politics of rural water governance in Bolivia Environment and Planning A 37 263-284

Polanyi K 2001 [1944] The Great Transformation: The Political and Economic Origins of Our Time Beacon Press, Boston

Pusey M 1991 Economic rationalism in Canberra: A nation-building state changes its mind Cambridge University Press, Cambridge

Rawls J 1999 A Theory of Justice Harvard University Press, Cambridge MA

Roberts A 2008 Privatizing Social Reproduction: The Primitive Accumulation of Water in an Era of Neoliberalism Antipode 40 535-560

Rose N and Miller P 1992 Political Power beyond the State: Problematics of Government The British Journal of Sociology 43 173-205

Sagoff M 2008 The Economy of the Earth: Philosophy, Law, and the Environment Cambridge University Press, Cambridge

Sayer A and Storper M 1997 Ethics unbound: for a normative turn in social theory Environment and Planning D: Society and Space 15 1-17

Schlosberg D 2004 Reconceiving Environmental Justice: Global Movements And Political Theories Environmental Politics 13 517-540

Schlosberg D 2007 Defining Environmental Justice: Theories, Movements, and Nature Oxford University Press, Oxford

Schlosberg D 2013 Theorising environmental justice: the expanding sphere of a discourse Environmental Politics 22 37-55

Smith A, Stenning A and Willis K eds 2008 Social Justice and Neoliberalism: Global Perspectives Zed Books, London

Smith DM 1994 Geography and Social Justice Blackwell, Oxford

Smith DM 2000 Moral Geographies: Ethics in a world of difference Edinburgh University Press, Edinburgh

Smith DM 2001 Geography and ethics: progress, or more of the same? Progress in Human Geography 25 261-268 
Smith L 2004 The murky waters of the second wave of neoliberalism: corporatization as a service delivery model in Cape Town Geoforum 35 375-393

Smith N 1996 Social Justice and the New American Urbanism: The Revanchist City in Merrifield A and Swyngedouw $\mathbf{E}$ eds The Urbanization of Injustice, Lawrence \& Wishart, London 117-136

Soja EW 1996 Margin/Alia: Social Justice and the New Cultural Politics in Merrifield A and Swyngedouw $\mathbf{E}$ eds The Urbanization of Injustice, Lawrence \& Wishart, London 180-199

Soja EW 2010a The city and spatial justice in Bret B, Gervais-Lambony P, Hancock C and Landy F eds Justices et Injustices Spatiales, Presses Univeritaires de Paris Ouest, Paris 55-74

Soja EW 2010b Seeking Spatial Justice University of Minnesota Press, Minneapolis

Springer S 2010 Neoliberalism and Geography: Expansions, Variegations, Formations Geography Compass 4 1025-1038

Swyngedouw E 2005 Dispossessing $\mathrm{H}_{2} \mathrm{O}$ : The Contested Terrain of Water Privatization Capitalism Nature Socialism 16 81-98

Swyngedouw E 2009 The Antinomies of the Postpolitical City: In Search of a Democratic Politics of Environmental Production International Journal of Urban and Regional Research 33 601-620

Swyngedouw E 2010 Trouble with Nature: 'Ecology as the New Opium for the Masses' in Healey $\mathbf{P}$ and Hillier $\mathbf{J}$ eds The Ashgate research companion to planning theory: Conceptual challenges for spatial planning, Ashgate, Farnham 299-318

Walker G 2009 Beyond Distribution and Proximity: Exploring the Multiple Spatialities of Environmental Justice Antipode 41 614-636

Walker G 2012 Environmental Justice: Concepts, evidence and politics Routledge, London

Wolford W 2005 Agrarian moral economies and neoliberalism in Brazil: competing worldviews and the state in the struggle for land Environment and Planning A 37 241-261

Wolford W and Nehring R 2013 Moral Economies of Food Security and Protest in Latin America in Barrett CB ed Food Security and Sociopolitical Stability, Oxford University Press, Oxford 302-322

Young IM 1990 Justice and the Politics of Difference Princeton University Press, Princeton NJ 
25

26

27

29

30

31

33

34

35

36

37

38

39

40

41

42
43

44

45

46

47

48

49

51

52

53

54

55

57

58

59

60 
Table I: Approaches to justice in the allocation of water in Australia

\begin{tabular}{|c|c|c|c|c|}
\hline $\begin{array}{l}\text { 'Bucket' of } \\
\text { water }\end{array}$ & Importance of justice & $\begin{array}{l}\text { Type of justice } \\
\text { pursued }\end{array}$ & $\begin{array}{l}\text { Provision of } \\
\text { justice }\end{array}$ & $\begin{array}{l}\text { Philosophy } \\
\text { of justice }\end{array}$ \\
\hline $\begin{array}{l}\text { Basic human } \\
\text { needs }\end{array}$ & Very important & $\begin{array}{l}\text { Distributive } \\
\text { (equality) }\end{array}$ & $\begin{array}{l}\text { Government } \\
\text { legislation and/or } \\
\text { regulation }\end{array}$ & $\begin{array}{l}\text { Liberal } \\
\text { egalitarian }\end{array}$ \\
\hline Environmental & $\begin{array}{l}\text { Important in the } \\
\text { transition from an over- } \\
\text { allocated to a } \\
\text { sustainable system }\end{array}$ & $\begin{array}{l}\text { Distributive } \\
\text { (proportionality) } \\
\text { Procedural }\end{array}$ & $\begin{array}{l}\text { Government } \\
\text { compensation } \\
\text { through market buy- } \\
\text { backs and direct } \\
\text { assistance }\end{array}$ & Utilitarian \\
\hline $\begin{array}{l}\text { Consumptive } \\
\text { pool }\end{array}$ & $\begin{array}{l}\text { Ambiguous; spectrum } \\
\text { from assuming the } \\
\text { market is just to } \\
\text { asserting the market is } \\
\text { just }\end{array}$ & $\begin{array}{l}\text { Distributive } \\
\text { (proportionality) } \\
\text { Procedural }\end{array}$ & $\begin{array}{l}\text { Trading of water } \\
\text { entitlements }\end{array}$ & Libertarian \\
\hline
\end{tabular}

